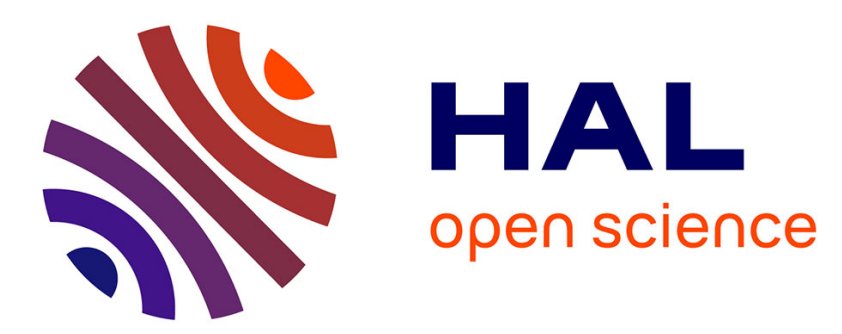

\title{
OMCVD on Fluidized Divided Substrates : a Potential Method for the Preparation of Catalysts
}

\author{
R. Feurer, A. Reynes, Philippe Serp, Philippe Kalck, R. Morancho
}

\section{To cite this version:}

R. Feurer, A. Reynes, Philippe Serp, Philippe Kalck, R. Morancho. OMCVD on Fluidized Divided Substrates : a Potential Method for the Preparation of Catalysts. Journal de Physique IV Proceedings, 1995, 05 (C5), pp.C5-1037-C5-1043. 10.1051/jphyscol:19955122 . jpa-00253793

\section{HAL Id: jpa-00253793 https://hal.science/jpa-00253793}

Submitted on 1 Jan 1995

HAL is a multi-disciplinary open access archive for the deposit and dissemination of scientific research documents, whether they are published or not. The documents may come from teaching and research institutions in France or abroad, or from public or private research centers.
L'archive ouverte pluridisciplinaire HAL, est destinée au dépôt et à la diffusion de documents scientifiques de niveau recherche, publiés ou non, émanant des établissements d'enseignement et de recherche français ou étrangers, des laboratoires publics ou privés. 


\title{
OMCVD on Fluidized Divided Substrates: a Potential Method for the Preparation of Catalysts
}

\author{
R. Feurer, A. Reynes, P. Serp*, P. Kalck* and R. Morancho \\ Laboratoire de Cristallochimie, Réactivité et Protection des Matériaux, URA 445 du CNRS, ENSCT, \\ 118 Route de Narbonne, 31077 Toulouse cedex, France \\ * Laboratoire de Chimie des Procédés, ENSCT, 118 Route de Narbonne, 31077 Toulouse cedex, France
}

\begin{abstract}
The OMCVD method has been used to deposit highly pure metal particles on porous divided substrates in order to prepare metal supported catalysts. A fluidized bed reactor has been especially designed and the requirements of CVD and fluidization have been taken into account to select convenient experimental conditions. Three organometallic compounds of rhodium have been selected and their thermal decomposition under $\mathrm{He}$ and $\mathrm{He} / \mathrm{H} 2$ mixtures studied by infrared spectroscopy and on-line mass spectrometry analyses. The deposition are carried out at a total pressure of 100 Torr and substrate temperatures as low as $100^{\circ} \mathrm{C}$. The solid deposits have been characterized by XPS, the size and dispersion of the particules have been determined by chemisorption methods or measured by TEM. These catalysts can be used without further treatment and their performances have been compared to those of conventionally prepared ones.
\end{abstract}

\section{INTRODUCTION}

Metal supported catalysts are constituted by metal particles dispersed on the surface and in the porosity of porous divided supports such as silica. The activity of a catalyst is strongly related to the purity of the metal, the size and the dispersion of the metal particles. Typical catalysts contain 1-5\% w/w metal/support with particles size ranging from 1 to $5 \mathrm{~nm}$. Usually they are prepared via impregnation of the support by a metallic salt or an organometallic solution followed by drying, calcination and several steps of reduction or oxidation to obtain the active form. These preparations require a long time and have not a perfect reproducibility.

We have thought that CVD may constitute an interesting way to prepare metal supported catalysts. The great number of organometallic compounds of noble metals and the weak probability to form oxides or carbides allow to obtain pure metal at low temperature. The OMCVD of rhodium has been developped recently, essentially for micro electronic applications and various precursors have been proposed [1-5].

In our case the required deposit is not a film but isolated small metal particles dispersed on the surface or in the porosity of powdery supports. Consequently we have thought to combine the fluidization technique with the chemical vapor deposition and to work at low pressure to increase mass transport in the pores.

A few works have been reported about fluidized bed chemical vapor deposition [6-10]. This technique is presently studied in our laboratory in collaboration with a chemical Engineering Laboratory [11].

\section{CHOICE OF THE EXPERIMENTAL CONDITIONS}

The problem consists in combining the requirements of the classical CVD parameters (Temperature of precursor in the sublimator : $T_{S}$, molar ratio of precursor : $x$, temperature of decomposition : $T_{d}$, total pressure : Ptotal) together with the gas flow velocity required to have a good fluidization of the powdery supports (related to the size, density, form of the grains). 


\subsection{Rhodium precursors}

We have selected three compounds $\mathrm{Rh}_{2} \mathrm{Cl}_{2}(\mathrm{CO})_{4}$ (I), $\mathrm{Rh}$ (allyl) 3 (II) and $\mathrm{Rh}(\mathrm{CO})_{2}\left(\mathrm{C}_{5} \mathrm{H}_{7} \mathrm{O}_{2}\right)$ (III). They have been synthesized in the laboratory and a more simple procedure for (I) has been proposed [12]. All of them are solids at room temperature and can be handled in air without decomposition.

In order to control the molar ratio of the precursors in the CVD process we have determined their vapor pressure laws [12-13].

$$
\begin{array}{llll} 
& \log P_{\text {torr }}=\frac{a}{T(K)}+b & \\
a=-3026 K & b=9,42 & \text { for } & \text { (I) } \\
a=-3069 K & b=10,41 & \text { for } & \text { (II) } \\
a=-4425 K & b=12,07 & \text { for } & \text { (III) }
\end{array}
$$

Consequently the molar ratio have been adjusted to around $10^{-3}$, corresponding to the various temperatures of sublimation

$$
\begin{aligned}
& 50-53^{\circ} \mathrm{C} \text { for (I) } \\
& 34-42^{\circ} \mathrm{C} \text { for (II) } \\
& 58-65^{\circ} \mathrm{C} \text { for (III) }
\end{aligned}
$$

The temperatures of pyrolysis have been determined using a classical horizontal hot wall reactor. The carrier gas was Helium and a typical total pressure was 100 Torr.

When a few amounts of dihydrogen $(\sim 10 \%)$ are added to the gas phase the deposition temperatures are greatly lowered.

\begin{tabular}{|c|c|c|c|}
\hline & $\begin{array}{c}{[\mathrm{RhCl}(\mathrm{CO}) 2] 2} \\
(\mathrm{I})\end{array}$ & $\begin{array}{l}\mathrm{Rh}(\text { ally) } 3 \\
\text { (II) }\end{array}$ & $\begin{array}{c}\mathrm{Rh}(\mathrm{CO})_{2}\left(\mathrm{C}_{5} \mathrm{H}_{7} \mathrm{O}_{2}\right) \\
\text { (III) }\end{array}$ \\
\hline $\begin{array}{c}\text { T sublimation } \\
\left({ }^{\circ} \mathrm{C}\right)\end{array}$ & 53 & 55 & 40 \\
\hline $\begin{array}{l}\mathrm{T} \text { decomposition } \\
\text { under } \mathrm{He}\end{array}$ & 125 & 135 & 100 \\
\hline $\begin{array}{c}\mathrm{T} \text { decomposition } \\
\text { under } \mathrm{He} / \mathrm{H}_{2}\end{array}$ & 75 & 85 & 60 \\
\hline $\begin{array}{c}\text { Volatil compounds } \\
\text { detected } \\
\text { under } \mathrm{He}\end{array}$ & $\mathrm{CO}$ & $\begin{array}{c}\mathrm{CO} \\
\mathrm{CO} 2 \\
\text { acetylacetone } \\
\text { acetone } \\
\text { butanone } \\
\end{array}$ & $\begin{array}{c}\text { propene } \\
\text { 1,5-hexadiene }\end{array}$ \\
\hline $\begin{array}{c}\text { Volatil compounds } \\
\text { detected } \\
\text { under } \mathrm{He} / \mathrm{H}_{2}\end{array}$ & $\begin{array}{l}\mathrm{CO} \\
\mathrm{HCl}\end{array}$ & $\begin{array}{c}\mathrm{CO} \\
\text { acetylacetone }\end{array}$ & $\begin{array}{c}\text { propane } \\
\text { 1,5-hexadiene } \\
\text { propene }\end{array}$ \\
\hline
\end{tabular}

The gaseous products of decomposition have been identified by using a quadrupolar mass spectrometer coupled to the reactor and by IR spectroscopy. All the results of decomposition experiments are reported in table 1.

Table 1 - Results of the decomposition of precursors. 


\subsection{Fluidization}

The support of the catalyst consists in porous silica grains which is known to participate to the catalytic process. The grains are characterized by a $100 \mu \mathrm{m}$ size, a 0.26 density, the shape factor 0.7 and the specific area $170 \mathrm{~m}^{2} \mathrm{~g}^{-1}$.

The fluidization tests show a good ability to fluidization and we have determined the minimum fluidization velocity Vmf and minimum ebullition velocity $V m b$ to be respectively $5.1 \mathrm{~cm} \mathrm{mn} n^{-1}$ and $20 \mathrm{~cm} \mathrm{mn}^{-1}$ under ambiant temperature and pressure. In order to realize a good agitation of the grains and a satisfactory repartition of the deposits we have chosen to work with a flow velocity of $47 \mathrm{~cm} \mathrm{mn}^{-1}$.

As seen above the sublimation of the precursors requires a low total pressure and we did not find in the literature any examples of low pressure fluidization. The total pressure of 100 torr was selected and we adjusted the value of the gas flow velocity in the reactor to the desired fluidisation velocity $V_{f}$ by using the equation :

$$
V_{f}=\frac{\text { total gas flow rate }}{\text { reactor section }} \frac{P_{a t m}}{P_{\text {Total }}}
$$

An experimental reactor has been especially designed and is displayed in figure 1 .

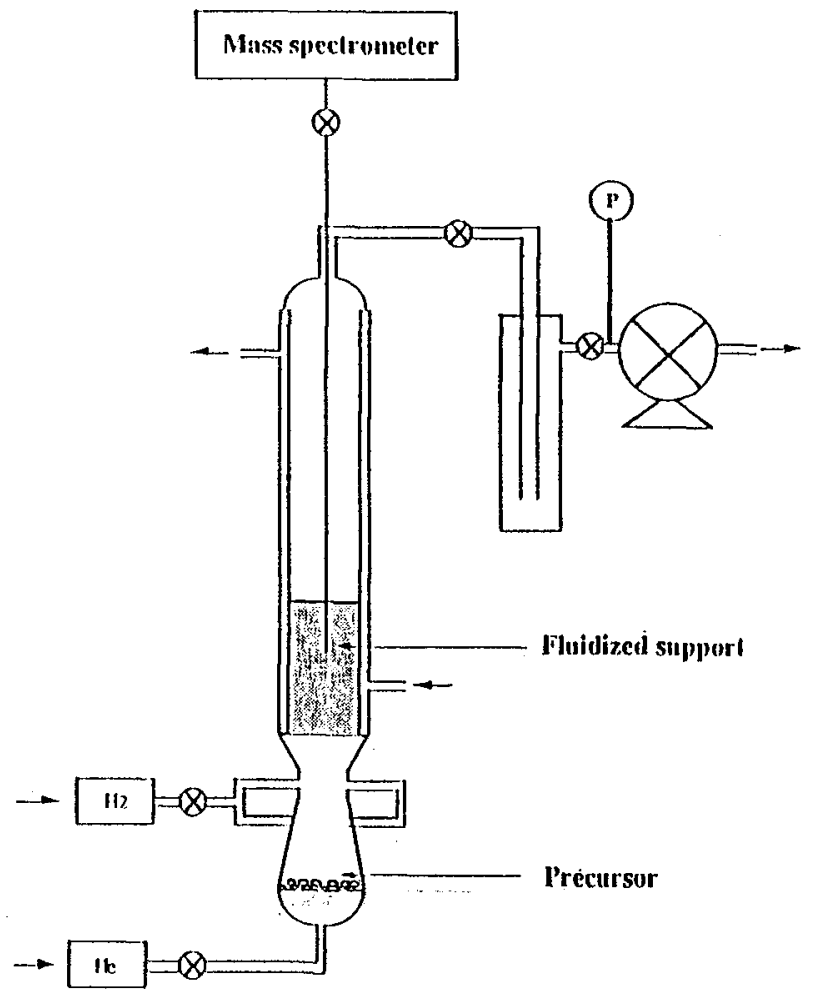

Figure $1:$ Schematic diagram of the fluidized bed CVD reactor 
The precursor is introduced in the sublimator (lowest part of the reactor) on a porous glass support and heated by a water bath at the desired temperature. The carrier gas flows up through the precursor and hydrogen is added to the gas mixture precursor/helium just before the entrance in the fluidized bed. The silica $(5 \mathrm{~g})$ is placed on an inox grid $(25 \mu \mathrm{m}$ holes) and heated by hot fluid circulation in the double jackuet of the column. The pressure is adjusted to 100 Torr by using a vacuum pump and two valves. The typical flow rate conditions are $55 \mathrm{sccm}$ for $\mathrm{He}$ and $8.5 \mathrm{sccm}$ for $\mathrm{H} 2$. The temperature of the sublimator and the fluidized bed are chosen from the preliminary results (1.1). Catalysts containing $1-5 \% \mathrm{wt} \mathrm{Rh}$ on $5 \mathrm{~g}$ silica are prepared 2 to 5 durationshours and can be immediatly used.

The reactor is coupled to a mass spectrometer by a capillary tube in order to analyse on-line the gaseous products of decomposition.

\section{RESULTS}

2.1 - Analysis of the deposits

Preliminary experiments on silicon, silica or glass plates have been carried out in order to characterize the deposit compositions by XPS, EDS and XRD.

X-Ray diffraction patterns correspond in all cases to metallic rhodium. XPS analysis show the presence of $\mathrm{Rh}^{\circ}\left(\mathrm{E}_{3} \mathrm{~d} 5 / 2=312.0 \mathrm{eV}\right)$ with chlorine $\left(\mathrm{E}_{2 \mathrm{p} 3 / 2}=197.9 \mathrm{eV}\right)$ when starting from (I) and graphitic carbon $(\mathrm{E} 1 \mathrm{~s}=284.5 \mathrm{eV})$ when starting from (II) and (III). Semi quantitative compositions determined by using the Scofield coefficients [14] are reported in table 2. The addition of dihydrogen strongly reduces the amount of impurities and allows to obtain metallic rhodium particules of high purity in the case of precursor (I).

Table 2 - XPS analysis of deposits on planar substrates

\begin{tabular}{|c|c|c|c|c|}
\hline Precursors & $\begin{array}{l}\text { Deposits with } \\
\text { or without H2 }\end{array}$ & Rh. \% wt & C \% wt & $\begin{array}{c}\text { Cl } \\
\% \text { wt }\end{array}$ \\
\hline I & Without & 77 & - & 23 \\
\hline I & With & 98.5 & - & 1.5 \\
\hline II & Without & 81 & 19 & - \\
\hline II & With & 93 & 7 & - \\
\hline III & Without & 68 & 32 & - \\
\hline III & With & 86 & 14 & - \\
\hline
\end{tabular}

\section{2 - Deposition on the divided silica supports}

Most of experiments reported here have been realised by using $\mathrm{Rh}_{2} \mathrm{Cl}_{2}(\mathrm{CO})_{4}$ and a gas mixture $\mathrm{H}_{2} / \mathrm{He}$ : 1/4. The molar ratio $x$ of the precursor was $9 \cdot 10^{-4}$, the total pressure 100 Torr and the weight of silica $5 \mathrm{~g}$. Good catalysts required few quantities of rhodium on silica $(1-3 \% \mathrm{wt} / \mathrm{wt})$ with particle sizes around one nanometer.

The amount of deposited rhodium has been measured by chemical analysis and particles sizes have been determined indirectly by chemisorption of $\mathrm{CO}$, chemisorption of $\mathrm{H}_{2}$ or directly observed by TEM.

Moreover it is worth to mention that the specific area and the porosity of the substrate are not affected by the deposition.

All these results are reported in table 3. Figure 2 reports the size distribution of metal particles observed by TEM. 
The amount of rhodium metal is directly proportional to the duration of the deposition, while the size of particles increases. When the total pressure is lowered (last row of table 2) the growth rate increases proportionally to the pressures ratio and in all the experiments the whole quantity of precursor is consumed. The TEM observations show that the particles are well isolated and the results obtained by the different analytical methods are consistent. The specific area and porosity ot the support are not greatly modified analytical showing that the deposited metal do not obstruate the pores.

Table 3 - Characterization of catalysts obtained from precursor (I)

$\mathrm{T}(\mathrm{S})=59^{\circ} \mathrm{C} ; \mathrm{T}(\mathrm{Fb})=100^{\circ} \mathrm{C} ; \mathrm{P}(\mathrm{T})=100 \mathrm{Torr} ; \mathrm{He} / \mathrm{H} 2=40 / 10$

(a) $\mathrm{SiO}_{2}$ before deposition; (b) $\mathrm{P}(\mathrm{T})=50 \mathrm{~T}$

\begin{tabular}{|c|c|c|c|c|c|c|}
\hline \multirow{2}{*}{ Time } & \multirow{2}{*}{ Rh } & \multicolumn{3}{|c|}{ Size of the particles (nm) } & $\begin{array}{c}\text { Specific area } \\
\text { B.E.T. } \\
\left(\mathrm{m}^{2} . \mathrm{g}^{-1}\right)\end{array}$ & $\begin{array}{c}\text { Porosity } \\
\left(\mathrm{cm}^{3} . \mathrm{g}-1\right) 10^{-3}\end{array}$ \\
\cline { 3 - 7 } & \% wt & chem. CO & chem. $\mathrm{H}_{2}$ & TEM & & \\
\hline $0(\mathrm{a})$ & 0 & - & - & - & 170 & 315 \\
\hline 2.5 & 0.5 & 1.2 & - & - & 184 & - \\
\hline 5 & 1 & 1.4 & 1.7 & 1.8 & 178 & 289 \\
\hline 10 & 2 & 1.7 & 2.3 & - & 172 & - \\
\hline 15 & 3 & 3.0 & - & - & - & - \\
\hline $5(\mathrm{~b})$ & 2 & 1.5 & - & - & 180 & - \\
\hline
\end{tabular}

In order to compare the present catalysts to the conventional ones, hydrogenation experiments on 1-octene and benzene have been carried out because this reaction is very sensitive to the amounts of chlorine remaining on the catalysts. For a same loading of $1 \% \mathrm{wt}$ of $\mathrm{Rh}$, these catalysts are around $60 \%$ more active than those prepared by impregnation of $\mathrm{RhCl}_{3}, 3 \mathrm{H}_{2} \mathrm{O}$ and classic subsequent reduction steps.

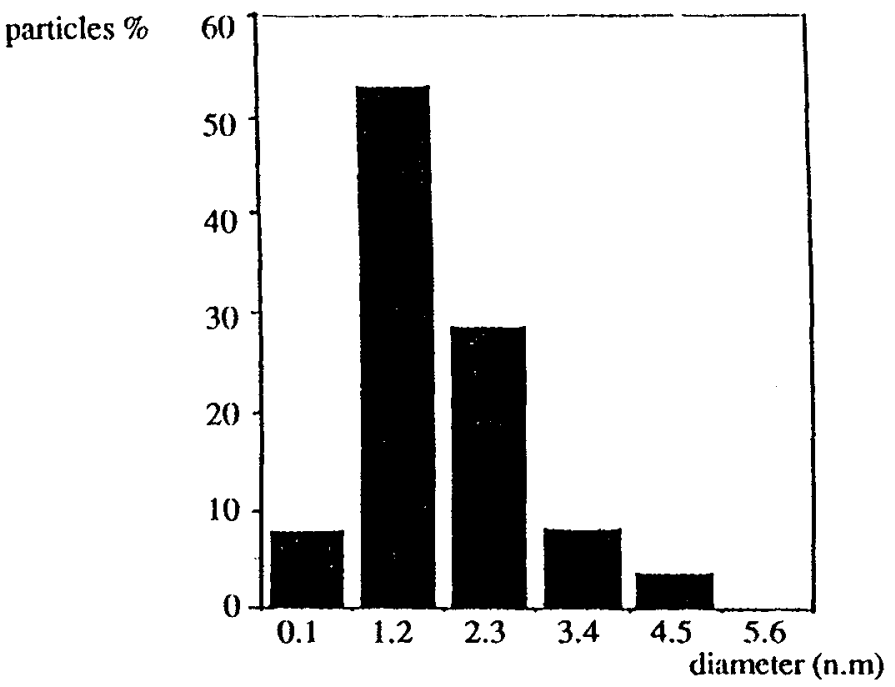

Fig. 2 : Size distribution of the Rhodium particles measured on TEM pictures 
2.3 Gaseous products of decomposition and attempts to explain the mechanisms of decomposition

Preliminary investigations on the mechanisms of decomposition have been carried out by studying the gas phase by infrared spectroscopy. Then, a mass spectrometer was coupled to the reactor to realize on-line analysis during the process.

An IR gas cell was charged with the precursor and $\mathrm{He}$ or $\mathrm{He} / \mathrm{H}_{2}$ mixture and slowly heated. The results have been reported in table 1 (vide supra).

With precursor (I) the only product detected under $\mathrm{He}$ above $125^{\circ} \mathrm{C}$ is carbon monoxide and the subsequent solid contains a $\mathrm{Rh} / \mathrm{Cl}$ ratio of 1 . With addition of $\mathrm{H}_{2}, \mathrm{HCl}$ appears in the IR spectra just after $\mathrm{CO}$ around $80^{\circ} \mathrm{C}$. In contrast to previous work (4) no $\mathrm{COCl}_{2}$ was detected even at higher temperatures.

In the case of precursor (III) the addition of hydrogen lowers by $50^{\circ}$ the temperature of decomposition and allows the elimination of the ligand acetylacetonate without breaking, contrarily to the case of pure He, giving a solid deposit containing less carbon (see table 2 XPS results). For the precursor (II) the consequences of the addition of $\mathrm{H}_{2}$ are similar : temperature of decomposition is $50^{\circ}$ lower and less carbon is incorporated in the solid. $\mathrm{H}_{2}$ contributes to hydrogenate propene into propane. These results differ from those of Kumar and Puddephat (4) and reveal gas phase reactions between the precursors and $\mathrm{H}_{2}$ more important in our case (hot wall reactor) than in the Kumar experiments (cold wall reactor).

The on-line mass spectrometric measurements reveal the evolution of the reactions along the experiments in the fluidized bed deposition process.

For example when starting a deposition process on silica, $\mathrm{CO}$ and $\mathrm{HCl}$ are not detected immediatly (few minutes of initiation) whereas the detection is immediate when very small amounts of $\mathrm{Rh}$ have been previously deposited on the silica. In the same way, if the flow of dihydrogen is cut off during the deposition the process goes on giving $\mathrm{CO}$ and $\mathrm{HCl}$ during 20 minutes. These observations are consistent with an autocatalytic behaviour of the deposition reaction.

In the case of (II) we can see in figure 3 the evolution of the relative quantities of propane, propene as a function of the $\mathrm{H}_{2}$ flow rate followed by mass spectrometry.

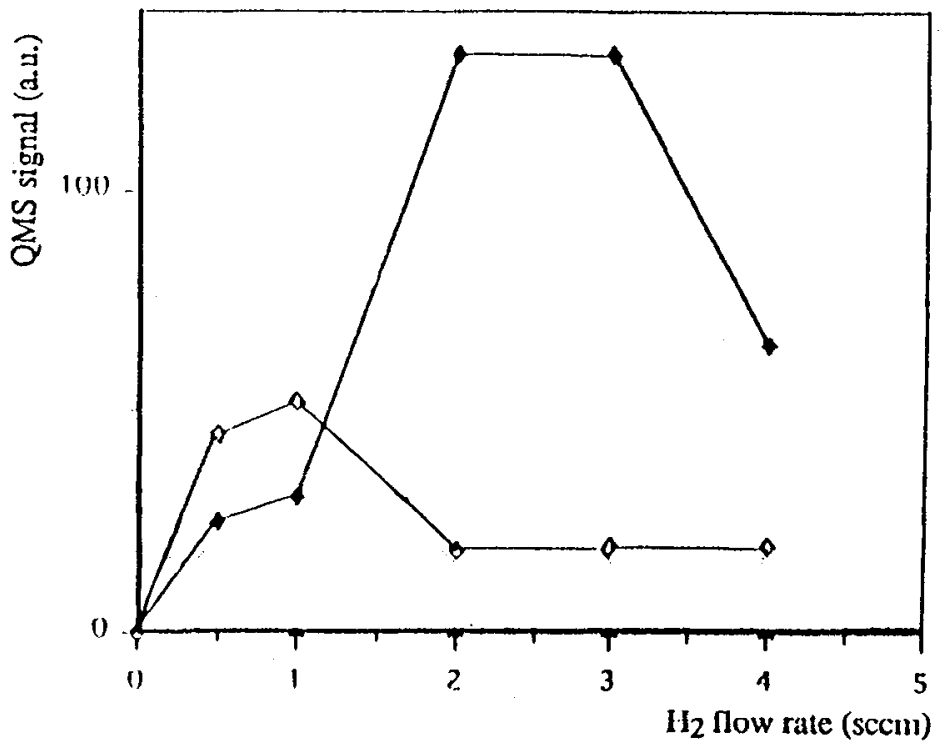

Fig. 3 : Variation of the quantities of propane and propene formed by decomposition of (II) as a function of $\mathrm{H}_{2}$ flowrate.

$\rightarrow$ fragment $\mathrm{m} / \mathrm{e}=29$ : propane ; $\diamond$ fragment $\mathrm{m} / \mathrm{e}=41$ : propene 
Further works are under way in order to elucidate the mechanism with precursor (I). We think that it proceeds by a first step of hydrogenation of $\mathrm{Rh}_{2} \mathrm{Cl}_{2}(\mathrm{CO})_{4}$ but till now no intermediate species has been detected.

\section{CONCLUSION}

OMCVD has been used to deposit under reduced pressure nanometric particles of rhodium on porous silica powder by using a fluidized bed reactor. The addition of dihydrogen allows to realize the deposition at temperatures as low as $80^{\circ} \mathrm{C}$ and to reduce the content of impurities. The careful control of the gas mixture composition and the growth rate allows to obtain isolated particles ranging from 1 to 2 nanometers with a satisfactory dispersion and a high purity of the metal. The catalysts can be used without any further treatment. The catalysts prepared by this method present better properties than the conventional ones.

\section{REFERENCES}

[1] Smith D.C., Pattillo S.G., Elliott N.E., Zocco T.G., Laia J.R. and Sattelberger A.P., "Proceedings of the 11th conference on CVD", K.E. Spear Ed., (1990), 610.

[2] Flint E.B., Messelhäuser J.and Suhr H., Applied Surface Science, 54, (1992), 56.

[3] Doppelt P., Ricard L. and Weigel V., Inorg. Chem., 32, (1993), 1039.

[4] Kumar R. and Puddephatt R.J., Can J. Chem., 69, (1991), 108.

[5] Yuang and Puddephatt R.J., Advanced Materials, 6, (1994), 51

[6] Galerie A., Le Du G., Caillet M., Mani P.A., Pingaux B., J.Phys., 5, (1989), 709.

[7] Sanjurjo A., Wood B.J., Lau K.H., Tong G.T., Choi D.K., Mc Kube M.C.H. , Sorg H.K., Surf. and Coatings Technol., 49, (1991), 103.

[8] Morooka S., Kobata A., Kusakabe K.,

A.I.ch.E. Symp. Series, 87, (1991), 32.

[9] Caussat B,

Thesis, Institut National Polytechnique, Toulouse Fr. (1994).

[10] Proceedings of the conference of chemical vapor deposition, 5th International Conference, Edit. J.M. Blocher, (1975), 509, 717, 727

[11] Caussat B., Serp P., Rodriguez R., Feurer R., Hemati M., Kalck P. , Couderc J.P., 5th Congrès Français de Génie des procédés, Lyon, France, Sept. 1995.

[12] Serp P.,

Thesis, Institut National Polytechnique, Toulouse Fr. 1994.

[13] Tobaly P. and Lanchec G.,

J. Chem. Thermodynamics, 25, (1993), 503.

[14] Scofield J.H.,

J. Electron. Spectros. Rel. Phenon., 8, (1976), 129. 
